\title{
Value Chain and Industry 4.0: A Learning from Sritex Experience
}

\author{
Hani Sirine $^{1 *}$, Roos Kities Andadari ${ }^{2}$ \\ ${ }^{1,2}$ Faculty of Economics \& Business, Universitas Kristen Satya Wacana, Salatiga 50711, Indonesia
}

\begin{abstract}
A B S T R A C T
The implementation of ' Industry $4.0^{\prime}$ brings consequences to industry, market and economy, including Textile and Textile Products which is one of the leading sectors in Indonesian export products. The use of more efficient technologies into alternatives that need to be developed to encourage increased productivity and investment in the TPT industry sector. Sritex as one of the fastest growing textile companies has also implemented Industry 4.0. In this research, will be analyzed about the Sritex value chain, the application of Industry 4.0 on the Sritex value chain, and the impact of the application of the Industry 4.0. The type of this research is qualitative research, where data obtained through secondary data contained in company profile, annual report Sritex, and articles related to Sritex. The result of this research is the application of Industry 4.0 technology in the Sritex value chain affecting products and processes, and enabling increased efficiency and productivity of the company. Application of Industry 4.0 affects 3 (three) interactive components of the organization and is highly interdependent, among them technology, structure, and people along the Sritex value chain.
\end{abstract}

ART I CLE IN F O

\author{
Article History: \\ Received : 26-06-2019 \\ Revised : 27-08-2019 \\ Accepted : 06-09-2019 \\ Published : 28-10-2019
}

Keywords:

Industry 4.0,

Value Chain,

Organizational Change Theory

*Corresponding Author E-mail:

hani.sirine@uksw.edu

Copyright (C) 2019 Authors. This is an open access article distributed under the Creative Commons Attribution License, which permits unrestricted use, distribution, and reproduction in any medium, provided the original work is properly cited.

\section{INTRODUCTION}

The term 'Industry 4.0' was created to mark the fourth industrial revolution, a new paradigm made possible by the introduction of the Internet of Things (IoT) into the production and manufacturing environment. This virtualphysical system allows smart factories to operate independently (Tjahjono, 2017). This new industrial paradigm unites the digital and physical world through a cyber-physical system that has consequences for industry, markets, and economics, improves production processes and productivity, influences the entire product life cycle, creates new business models, changes the work environment, and restructures the power 
market work (Pereira \& Romero, 2017). One industry that is influenced by Industry 4.0 is the textile industry.

The textile industry has an important role because its products are always included in the top ten of Indonesia's non-oil exports, so TPT is one of the leading sectors in Indonesia's export products. Large groups in Indonesian TPT are geographically concentrated in five provinces in Java (Kuncoro, 2013). Industrial development must be supported to maintain their position and to increase their competitiveness abroad. In the main activities of the Indonesian textile industry, the biggest costs are inbound activities which reach 56\%-58\%. The largest component of production process costs is $27 \%$ of labor in the upstream industry, $6 \%-13 \%$ in the upstream and intermediate industries. Other cost components are energy costs of 15\% - 19\% for upstream and intermediate industries, while downstream industries are only 2\% (Irawan \& Suryatoga, 2009). To maintain the long-term growth of the textile industry, it is important to innovate and improve technology (Ghambir \& Sharma, 2015).

Indonesia's TPT industry needs to focus on research and development activities as well as design in the upstream and downstream marketing efforts to improve its position in the global value chain (Sudhana, 2017). The main performance indicators of the textile industry are analyzed, including quality, flexibility, supply chain management, strategy formulation, and strategy implementation. The potential for significant improvement is mainly indicated in the field of human resource management and knowledge management (Bilalis et al., 2006). The Indonesian TPT value chain system is composed of several vertically integrated system actors, interacting and reciprocally related. The system actors include suppliers, industry, and markets as consumer representations (Widodo \& Ferdiansyah, 2010).

The use of more efficient technology is an alternative that needs to be developed to encourage increased productivity and investment in the textile industry sector (Asmara et al., 2013). The use of intelligent technology support in the TPT supply chain is growing especially in the areas of RFID, mobile computation, technology decision making, and sustainable development (Ngai et al., 2014). The innovation that is happening now changes the landscape and business model of the textile industry. Industry 4.0 revolution influences the value chain where companies experience organizational, structural and technological changes (digitization process). For this reason, support from supply chain management is needed during the innovation and collaboration process needed for the success of a project (Ruel etal., 2013).

The value chain involves all activities in delivering products from raw materials to end customers. Value chain activities take place from the internal organization to external trading partners such as suppliers, operators, third party companies, and providers of information systems (Lam \& Postle, 2006). The application of Supply Chain Management (SCM) as a business philosophy requires collaboration and integrated behavior (Teng \& Jaramillo, 2006). Artificial intelligence can help in creating systems that make decisions and carry out actions for production and logistics in the value chain (Dopico et al., 2016). Good value chain performance is important for achieving competitive advantage, where logistics plays a strategic role in it. Performance in the field of logistics provides feedback in terms of timely, monitoring and improvement responses (Law, 2016).

A competitive market in the textile industry also requires an increase in rapid response and accurate responses in the overall business system (Chandra \& Kumar, 2000). Rapid response can increase competitiveness through technological capabilities and supply chain collaboration. Accurate response is done through the integration of forecasting, planning, and production activities that allow producers to make decisions about forecasts that are validated at the speed of sales (Hunter, 1990, Hunter \& Valentino, 1995). 
According to Bimbaum (2002), companies that are able to integrate and control various supply chains to optimize market requirements will dominate the industry.

Sritex as the largest textile company in Southeast Asia applies industry 4.0 in its value chain around 2013. It is located in Sukoharjo, Central Java, was established on May 22, 1978. Sritex manufactures a variety of global products. For example in the apparel sector (garment), several well-known fashion products such as Zara, Guess, and Timberland were also made at Sritex factory. Until now, at least 30 countries have ordered uniforms for their military forces to Sritex. Each country orders uniforms with diverse capabilities, for example anti-radiation ordered by the United Arab Emirates and Kuwait and anti-infrared ordered by Germany. Meanwhile for TNI, Sritex also produces uniforms with extraordinary capabilities, including anti-water, fire retardant and even mosquito repellent. In this study, it will be analyzed about Sritex value chain, the application of industry 4.0 in Sritex value chain, and the impact of the application of industry 4.0. The contribution of this research to Sritex is that Sritex can find out the added value of the application of industry 4.0 in its value chain and take proactive actions to improve its performance.

\section{LITERATURE REVIEW}

\section{Value Chain}

Krajewski \& Ritzman (2001) define the value chain as a set of linkages between suppliers of materials and services that include the transformation of raw materials into products and services. Mentzer, et al. (2001) states that there are three or more entities (organizations or individuals) that are directly involved in the upstream and downstream flows of products, services, finance, and/ or information from sources to customers.

Value chains are defined as a chain of valueadded activities, products that pass through activities in a chain and get value at each stage (Porter, 1985). The value chain concept is used for the organization's supply chain network. Need to add value for every activity that the product / service goes through the product life cycle. Porters develop general-purpose value chains that manufacturing companies can use to examine all their activities, and to see how they are connected. The value chain activity of an organization determines costs, thus affecting earnings. Value chain analysis is useful for analyzing sources and increasing organizational value. The value chain focuses on the system, and how business inputs are transformed into business outputs purchased by customers. The value chain developed by Porter is shown in Figure 1 below.

\section{Value Chain - Primary Activities}

The main activities are activities that are directly involved in the process of converting raw materials into output/final products including the receipt of basic raw materials from suppliers and marketing of products/products to customers (Porter, 1985). These activities are grouped into

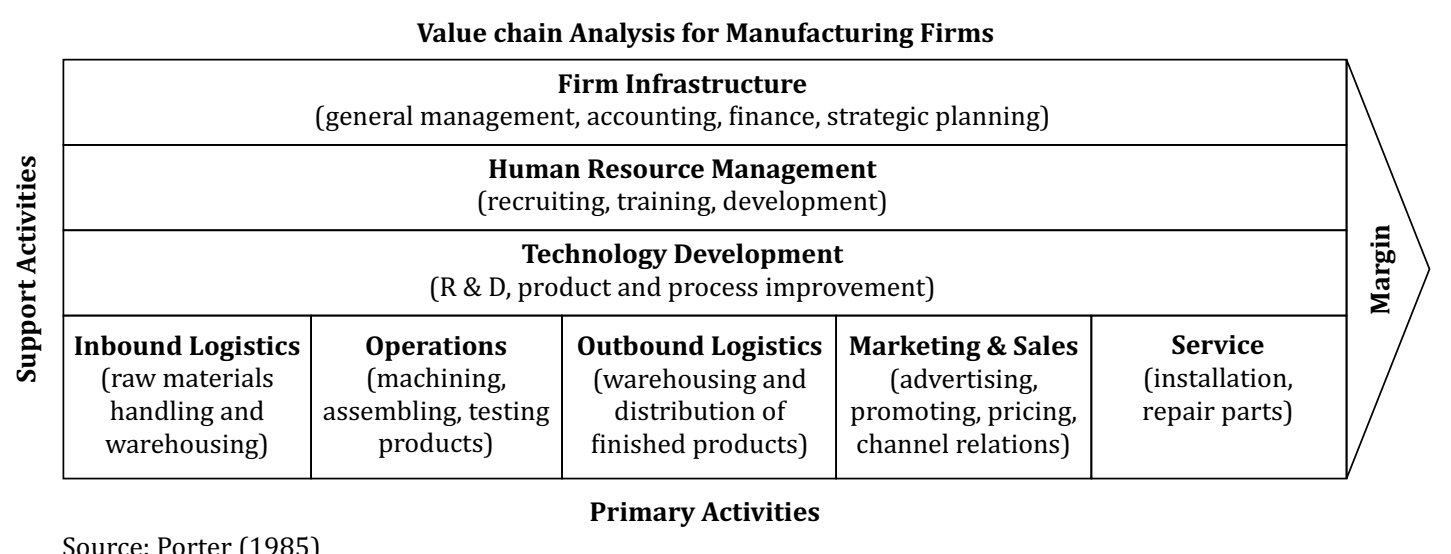

Figure 1. Value Chain Analysis of Manufacturing Companies 
two types of activities related to products and markets. Product related activities are activities carried out by organizations to add value to the products and services themselves. Activities related to markets are activities carried out by organizations to transfer finished products or services to customers.

Inbound logistics is receiving basic raw materials needed for the process of making products, stacking and recovering materials, and distributing materials to various departments, etc. Inbound Logistics activities can be included in the main activities. Operations are handling and processing raw materials (receiving and handling the main raw material). Outbound logistics are planning and delivery, management of distribution, transportation, warehousing, and fulfillment of orders.

Outbound logistics activities can be included in the main activities. Marketing and sales are product management, price management, placement management (distribution), promotion management, domestic sales (project sales, actual user sales, retail sales), export sales, special product sales, planning and shipping, prices and policies, contracts, customer relationship management, and others. Marketing and Sales activities can be included in the main activity. The services are quality aspects, shipping aspects, pre/post sales contacts, complaint resolution procedures. After-sales activity services can be included in the main activities.

\section{Value Chain -Support Activities}

Supporting activities are those activities that are not directly involved in the conversion process but support the main activities in their functions (Porter, 1985). The firm infrastructure are general management, accounting and finance management, and strategic planning. General management consists of office management, corporate strategic management, corporate communication, information technology (process control, material management systems, marketing systems, payroll systems, and financial accounting systems). Accounting and finance management consists of treasury management, budgeting, costing, company accounts, raw material accounts, sales financing, operations \& general accounts and work accounts, central excise and insurance, parts of payments (current employee payments and payments to retired employees), save accounts, buy bills (payments for domestic and imported materials), project accounts, internal audits and stock verification. Strategic planning consists of design \& engineering activities for existing factories, project contracts, construction, and project planning for plant expansion.

Human resource management are corporate coordination (workforce planning, recruitment, executive formation, rules \& policies, welfare, parliamentary cells). Human resources-nonwork (development of human resources, nonemployment personnel, mining, industrial relations, SC \& ST cell, sports). Human resourcesfactories (factory personnel), management services (quality circles, advice schemes, awards, incentive schemes), corporate social responsibility, medical, city administration, administration (general administration, law, hospitality, RTI, Liaison Office, Agro Forestry). Human Resource Development (training, management development, HR information systems).

Technology development are quality assurance and technology development (QA \& TD), research and development (R \& D), automation processing, and others. The procurement are you identify sources for various materials, select suppliers, take requests from the factory unit (pivot), process indents, procure raw materials, components and parts, machinery and spare parts, consumables, stationery, service, ensure material supply, etc.

\section{Application of Industry 4.0 in Value Chain}

The fourth industrial revolution often referred to as industry 4.0 involves rapid changes and affects manufacturing digitalization, network communication, computer technology and automation, and many other relevant fields (Zhou et al., 2016). This new industry paradigm includes a range of technological developments, such as CPS, IoT, robotics, big data, cloud 
manufacturing, and augmented reality, which will affect products and processes, enabling increased efficiency and productivity among companies that will adopt the technology (Schmidt et al., 2015). Furthermore industry 4.0 will cause profound changes in the industrial and manufacturing sectors, have a strong impact along the value chain and provide a range of new opportunities regarding business models, production technology, creation of new jobs and work organizations.

Various applications for industrial 4.0 technology in manufacturing logistics have been identified and placed in four groups, namely decision support and decision-making; identification and interconnectivity; seamless information flow; and automation, robots \& new production technology (Strandhagen, et al., 2017), as shown in Table 1 below.

The industry 4.0 concept of the supply chain includes activities such as: procurement, production, distribution, and sales that are linked to smart factory technology and smart logistics. The biggest impact of organizational change is in the production and distribution process, while the sales process faces moderate impact. The procurement process has the least impact on Industry 4.0 technology (Dangelmaier et al., 2001). Autonomic decisions based on pre-implementation algorithms are needed in the autonomization process in the digital supply chain (Coyle \& Ruamsook, 2014).

The benefits of additive manufacturing methods compared to conventional manufacturing methods are the feasibility of reducing untruth and customization of designs (Holmstrom et al., 2010). Robotic systems provide corporate benefits because they reduce production costs (Potkonjak et al., 2000). Technology helps workers through the integration of information into the work environment, reduces the cognitive burden on workers and enables better performance of various operations in the field of logistics and manufacturing (Wang, etal., 2016).

\section{Impact of Implementation of Industry 4.0}

There are two theories used to find out the impact of industry 4.0 on the value chain, namely the theory of organizational change by Leavitt (1965) or what is called the horizontal dimension and the model of supply chain activities by Meyr \& Wagner (2004) cited in Kannegiesser (2008) or which is called the vertical dimension. Leavitt's theory of organizational change states that each organization consists of three interactive and highly interdependent components, namely technology, structure, and people. These things are explained in Table 2 below.

Table 2. Components of Organizational Change

\begin{tabular}{|l|l|}
\hline $\begin{array}{c}\text { Component of } \\
\text { Organizational } \\
\text { Change }\end{array}$ & \multicolumn{1}{c|}{ Information } \\
\hline Technology & $\begin{array}{l}\text { These are physical assets such as machines } \\
\text { or knowledge-based assets such as patents. }\end{array}$ \\
\hline Structure & $\begin{array}{l}\text { It is all communication systems, authority } \\
\text { systems, and workflow systems within an } \\
\text { organization. }\end{array}$ \\
\hline Person & $\begin{array}{l}\text { Referring to the human domain in an } \\
\text { organization, this framework covers all } \\
\text { human-related problems, from recruitment } \\
\text { and personnel education to organizational } \\
\text { interactions in the social system. }\end{array}$ \\
\hline
\end{tabular}

Source: Leavitt (1965)

The application of artificial intelligence in smart factories has proven to have a large impact on the productivity and quality of the products produced (Li, et al., 2017). Organizations carry out planning,

Table 1. Application of Industry 4.0 in the Value Chain

\begin{tabular}{|c|c|c|c|}
\hline $\begin{array}{c}\text { Decision Support and } \\
\text { Decision-Making }\end{array}$ & $\begin{array}{c}\text { Identification } \\
\text { and Interconnectivity }\end{array}$ & $\begin{array}{c}\text { Seamless } \\
\text { Information Flow }\end{array}$ & $\begin{array}{c}\text { Automation, Robots and } \\
\text { New Production Technology }\end{array}$ \\
\hline Artificial intelligence & Sensors & Real-time control & Industrial robots \\
Big data analytics & Auto ID & Integration of IT systems & 3D printing \\
Augmented and virtual reality & Networking technology & Cloud computing & Automatic Guided Vehicles \\
\hline
\end{tabular}

Source: Strandhagen, et al (2017) 
decision making, control, and initiation through the autonomization of logistics (Broy, 2011). Stock \& Seliger (2016) explain the development towards a production situation where robots and human workers are very integrated and work collaboratively on shared tasks.

\section{RESEARCH METHOD}

This type of research is qualitative research. Data is obtained through secondary data contained in company profile, annual reports, and articles about Sritex. After the data is collected then narrated with arguments according to the theory used.

\section{RESULTS AND DISCUSSION}

\section{Sritex Value Chain}

Krajewski \& Ritzman (2001) define the value chain as a set of linkages between suppliers of materials and services that include the transformation of raw materials into products and services. Mentzer et al. (2001) states that there are three or more entities (organizations or individuals) that are directly involved in the upstream and downstream flows of products, services, finance, and/or information from sources to customers.

Value chains are defined as a chain of valueadded activities, products that pass through activities in a chain and get value at each stage (Porter, 1985). The value chain concept is used for the organization's supply chain network. Need to add value for every activity that the product / service goes through the product life cycle. Porters develop general-purpose value chains that manufacturing companies can use to examine all their activities, and to see how they are connected. The value chain activity of an organization determines costs, thus affecting earnings. Value chain analysis is useful for analyzing sources and increasing organizational value. The value chain focuses on the system, and how business inputs are transformed into business outputs purchased by customers.

Inbound logistics is receiving basic raw materials needed fo $r$ the process of making products, stacking and recovering materials, and distributing materials to various departments, etc. Inbound Logistics activities can be included in the main activities. Sritex has a rayon factory in Sukoharjo, Central Java, which is managed by its subsidiary, PT Rayon Utama Makmur. Sritex builds a rayon plant which will produce yarn. The production facility consists of two lines with a total capacity of 80 thousand tons per year. The rayon plant is also equipped with a 30 megawatt steam power plant. Sritex began to push I nto the upstream sector because it wanted to strengthen the independence of national clothing by using local raw materials.

The operations are handling and processing raw materials (receiving and handling the main raw material). Sritex applies the principle of planning in stages to carry out its business activities starting from the process of selecting raw materials, capabilities and mastery of the production process, to marketing strategies that are all done creatively with good and systematic directions with the main targets: International Scale Textiles and Garments Plant. Sritex has four main production processes as described in Table 3 below:

Table 3. Sritex Production Process

\begin{tabular}{|l|l|}
\hline $\begin{array}{l}\text { Production } \\
\text { Process }\end{array}$ & \multicolumn{1}{c|}{ Explanation } \\
\hline Spinning & $\begin{array}{l}\text { The spinning division converts fiber into yarn. Sritex continues to increase its production through upgrading } \\
\text { with the latest machines \& advanced technology. Satisfying 14 spinning mills (including PT Sinar Panja Djaja) } \\
\text { with a total of 5,000 employees. The spinning division is supported by 2,500 machines with more than 530,000 } \\
\text { ring-spindle \& modification machines imported from Europe \& Asia. }\end{array}$ \\
\hline Weaving & $\begin{array}{l}\text { The weaving division converts yarn to greige. Employing extraordinary technology to produce various types of } \\
\text { fabrics with light, medium and heavy construction. Consisting of 3 weaving factories with 4,000 employees. } \\
\text { The weaving division is supported by 2,600 weaving machines, including high-speed looms. }\end{array}$ \\
\hline
\end{tabular}




\begin{tabular}{|l|l|}
\hline $\begin{array}{l}\text { Dyeing \& } \\
\text { Printing }\end{array}$ & $\begin{array}{l}\text { With more than } 45 \text { years of experience in Dyeing and Printing, Sritex has become a role model for world-class } \\
\text { textile companies. Dyeing \& printing convert greige into finished fabric. It consists of 1,000 employees and is } \\
\text { supported by } 3 \text { continuous-dyeing production lines, 9 rotary printing machines, } 12 \text { jet dyeing machines, } \\
9 \text { stenter machines. }\end{array}$ \\
\hline Garment & $\begin{array}{l}\text { Sritex has succeeded in completing a one-stop "super mall", a world-class textile company by establishing } \\
\text { a Garment unit. The Garment Division transforms cloth into ready-made clothing. Consisting of 7,000 employees } \\
\text { in 8 garment units supported by 6,350 machines. Production capacity of 8,200,000 ready-made garment units } \\
\text { per year. }\end{array}$ \\
\hline
\end{tabular}

Source: Company Profile and Sritex Annual Report (2018)

Outbound logistics are planning and delivery, management of distribution, transportation, warehousing, and fulfillment of orders. Outbound logistics activities can be included in the main activities. Sritex manufactures textile \& garment in the Army \& Institutional Uniform segment and the customer is middle up for garment products, so the product quality is the main emphasis of Sritex. In business Sritex is differentiated as a textile company that focuses on quality, and this tradition is able to be maintained by Sritex for the past 3 decades. By itself, Sritex has core competence which is difficult to be imitated by competitors. With a variety of fabrics and the ability to meet various needs, Sritex is able to penetrate the international fashion industry and serve well-known clients such as JC Penny, Sears, Wal-Mart, Timberland, GUESS, Quicksilver, Gymboree, Charles Vogele, Okaidi, Zara, and others. The business model developed by Sritex has placed a strong business positioning with the ability to compete both in terms of quality and price (integrated production capabilities). Sritex has won global recognition and served many countries around the world. Worldwide Sritex Customers List can be seen in Table 4 below:

Marketing and sales are product management, price management, placement management (distribution), promotion management, domestic sales (project sales, actual user sales, retail sales), export sales, special product sales, planning and shipping, prices and policies, contracts, customer relationship management, and others. Marketing and Sales activities can be included in the main activity. Sritex strives to continue to develop its business network by only opening 2 (two) marketing offices that are located in Jakarta and Surabaya to approach consumers, and facilitate them in getting services from the company while taking into account the side of profitability.

The marketing system used by Sritex is three types, namely direct sales (direct selling), the implementation of sales of orders (orders), and exports. Direct selling is by the way buyers come directly to the show room for both foreign and domestic tourists by cooperating with travel agencies. Foreign tourists come from various continents, including Asia, America, Europe, Australia and Africa. The implementation of sales of orders is categorized as non-fixed sales because it only waits for orders to make certain items with the agreed capital and type from private individuals and government agencies. Exports are carried out according to demand, which is influenced by the world economy which sometimes rises and sometimes falls.

Table 4. List of Sritex Customers

\begin{tabular}{|l|l|}
\hline AMERICA: & Argentina, Brazil, Canada, Chile, Colombia, Guatemala, Mexcio, Paraguay, Peru, USA, Uruguay. \\
\hline ASIA- PASIFIC: & $\begin{array}{l}\text { Australia, Bangladesh, Cambodia, China, Hongkong, India, Indonesia, Japan, Korea, Malaysia, Myanmar, Phillipines, } \\
\text { Papua Neu Guinea, Pakistan, Singapore, SriLanka, Taiwan, Thailand, Vietnam. }\end{array}$ \\
\hline EUROPE: & Belgium, Spain, Germany, Greece, Italy, Poland, Romania, Sweden, Turkey, United Kingdom, Austria. \\
\hline AFRICA: & Benin, Egypt, Ethiopia, Nigeria, South Africa, Somalia. \\
\hline MIDDLE EAST: & Israel, Morocco, Oman, Tunisia, United Arab Emirates. \\
\hline INDONESIA: & Irian Jaya, Jakarta, Magelang, Surabaya, Solo, Tasikmalaya, Tegal, Tulungagung. \\
\hline
\end{tabular}

Source: Company Profile and Sritex Annual Report (2018) 
Promotions used by Sritex are advertisements, forder, banners, and pamphlets. Sritex periodically advertises on mass media both at home and abroad. Sritex makes a forder, which is a selfmade advertisement media to be distributed to both current accounts and travel accounts directly to consumers. In collaboration with certain events, Sritex conducts promotions by installing banners or flyers. Promotions are indirectly carried out by Sritex by giving satisfaction to customers.

The services are quality aspects, shipping aspects, pre/post sales contacts, complaint resolution procedures. After-sales activity services can be included in the main activities. To maintain product quality, Sritex applies the AQL 2.5 quality control system that closely monitors all production activities from fabric inspection to garment sewing. This is continually enhanced by an independent quality control system that is carried out before the final inspection is carried out by the customer. High quality products and timely delivery have exceeded the expectations of a growing number of clients. Proof of Sritex has a strong tradition of quality by recognizing the quality of Sritex globally with Registered Supplier of Bundeswehr (German Army) and NATO Certificates where both are the highest quality standards for garment manufacturing for the military. On the national scale, Sritex received several awards, one of which was the Muri Record.

The firm infrastructure are general management, accounting and finance management, and strategic planning. General management consists of office management, corporate strategic management, corporate communication, information technology (process control, material management systems, marketing systems, payroll systems, and financial accounting systems). Sritex marketing system is a production marketing system. As a vertically integrated textile manufacturer capable of producing various mid-streams and downstream products, Sritex is able to market its products to various types of customers. Yarn and greige produced by Spinning Division and Weaving
Division are products with low variation levels so that they can be traded like commodities. Sritex stores most of the yarn and greige from the Spinning Division and Weaving Division, but also sells the product directly to other producers and wholesalers. Prices for orders that use a made to stock sales strategy are based on spot prices on the international market. Fabrics and garments produced by the Finishing Division and Garment Division have high variations. Therefore, the company sells according to individual orders or by giving advance payments. Then, the company produces it according to customerspecified orders. Prices for orders with a sales strategy made to order are determined based on order volume.

Sritex stipulates that the basic principles symbolized as "Main Pillars", which must be carried out by all employees to create values which will then shape the creation of good culture and corporate performance. Sritex prioritizes service to consumers such as the ease of visiting a location, providing vehicle facilities for smooth visits, providing a place to stay in an international standard hotel and providing guaranteed classrooms, so that consumers are more focused on their business goals with Sritex.

Accounting and finance management consists of treasury management, budgeting, costing, company accounts, raw material accounts, sales financing, operations \& general accounts and work accounts, central excise and insurance, parts of payments (current employee payments and payments to retired employees), save accounts, buy bills (payments for domestic and imported materials), project accounts, internal audits and stock verification. Since 2007, Sritex has changed the status of its company to a public company, so that the achievement of all business activities it has carried out can be developed even better. Valuation of the IPO Sritex plan on P.E. $12 \mathrm{x}-14 \mathrm{x}$ at a price of Rp. 230 to Rp. 385 is still relatively cheap. But the most important thing is Sritex's management commitment and Sritex's future growth prospects, making this company to be very attractive and attractive to become one of the stock portfolios. 
Strategic planning consists of design and engineering activities for existing factories, project contracts, construction, and project planning for plant expansion. Sritex is a company that has a strong corporate culture. Expansion plans for the scale of garment production and spining are expected to be able to encourage Sritex to make a leap in sales (revenue enhancement). Going forward, Sritex is building a strong branding with market expansion, especially garment products, through the plan to acquire several brands and make a number of outlets (show rooms). A strong global network with several global branding makes Sritex's position increasingly attractive on a business basis. Sritex is currently mature in the textile industry.

Human resource management are corporate coordination (workforce planning, recruitment, executive formation, rules \& policies, welfare, parliamentary cells). Human resources-nonwork (development of human resources, nonemployment personnel, mining, industrial relations, SC \& ST cell, sports). Human resources factories (factory personnel), management services (quality circles, advice schemes, awards, incentive schemes), corporate social responsibility, medical, city administration, administration (general administration, law, hospitality, RTI, Liaison Office, Agro Forestry). Human Resource Development (training, management development, HR information systems). HR is one of the strengths for the company's business customers. For this reason, Sritex regularly prepares highly competent employees to be included in the Training and Development Program to better master the field of work carried out inside or outside the country, with the aim not only that they can do their jobs correctly but can apply professionally in supporting the company's business as a whole.

Technology development are quality assurance and technology development (QA \& TD), research and development ( $\&$ \&), automation processing, and others. Supported by the Research and Development division, Sritex meets every customer's specific needs with its ability to create various types and specifications of fabrics from various materials and knitted models. Small examples of the success of the Sritex Research and Development Division include the creation of a variety of additional applications for fabrics in the form of water repellent, insect repellent, fire retardant, stain free, anti-infrared, light weight and porous that can be used for various types ingredients.

The procurement is identification of sources for various materials, select suppliers, take requests from the factory unit (pivot), process indents, procure raw materials, components and parts, machinery and spare parts, consumables, stationery, service, ensure material supply, etc. Sritex's vertical integration for upstream and downstream processes makes it possible to achieve economies of scale as well as textile one-stop shopping and garment supermarket concepts that provide a variety of products to service every customer demand. Sritex issues an efficient cost structure because of this vertical integration. In house production of threads, fabrics and garments in a value chain allows for optimal coordination and fast production. Sritex also does not incur transportation costs, because production is carried out under one roof, so short lead times and fast delivery.

\section{Application of Industry 4.0 in the Sritex Value Chain}

The textile industry in Indonesia is divided into three vertical and integrated sectors from upstream to downstream. The upstream sector is an industry that produces fiber (natural fiber and man made fiber or synthetic) and spinning processes into yarn products (unblended and blended yarn). This industry is capital intensive, full automatic, large scale, relatively small labor force and large labor output. At present Indonesia is the seventh largest producer of artificial fibers in the world that supplies $10 \%$ of the world's rayon fiber needs.

The medium industry sector (midstream) includes the process of interlacing threads into gray fabric through weaving and knitting processes which 
are further processed through dyeing, finishing and printing into finished fabric. Its industrial nature is semi capital intensive, intermediate and modern technology is growing steadily, and the workforce is larger than the upstream industry sector. The main markets for the weaving industry are countries in Europe and the Middle East.

Downstream industry is a garment manufacturing industry including the process of cutting, sewing, washing, and finishing which produces ready-made garment. This sector absorbs the most labor so that the nature of the industry is labor intensive. Most garment exports are carried out by large-scale garment companies.

Sritex have a unique entity in the entire textile industry because it has been integrated from upstream to downstream. Sritex integrates four production processes namely spinning, weaving, finishing and garment. This integration has not been considered sufficient, therefore Sritex is preparing an Industrial Plantation Forest business that can supply raw materials for rayon fiber for Sritex. Sritex implements automation, robotization, and digitalization almost on some production lines. Sritex as an international scale textile and textile product manufacturer has implemented industrial technology 4.0 and has succeeded in achieving efficiency while maintaining product quality.

The implementation of industry 4.0 on Sritex is first, Sritex consolidates in the production section to increase capacity to full. Second, Sritex consolidates two yarn spinning companies, PT Primayudha Mandirijaya and PT Bitratex Industries. Sritex acquired Primayudha Mandirijaya and Bitratex Industries with a value of US \$ 85 million or Rp. 1.14 trillion. Based on financial report data, during 2017, Sritex posted sales of US \$ 759.3 million, up $12 \%$ from the previous year. Third, Sritex improves the strategy so that the Research \& Development team can create new products, also increase existing market links so that they are bigger.

The industry 4.0 concept of the supply chain includes activities such as: procurement, production, distribution, and sales that are linked to smart factory technology and smart logistics. The biggest impact of organizational change is in the production and distribution process, while the sales process faces moderate impact. The procurement process has the least impact on Industry 4.0 technology (Dangelmaier et al., 2001). Autonomic decisions based on preimplementation algorithms are needed in the autonomization process in the digital supply chain (Coyle \& Ruamsook, 2014).

The application of industry 4.0 also occurs through each Sritex value chain. The digitization process occurred in the design system but could not be applied to the weaving system. The weaving system uses a robotic system, more towards the PLC (Programmable Logic Controller) system using algorithms to improve quality and efficiency. Spinning uses robotics to pick up items and others. For coloring work, use a digital print system. Additive manufacturing technology such as 3D printing can be a support for more individual production. The benefits of additive manufacturing methods compared to conventional manufacturing methods are the feasibility of reducing untruth and customization of designs (Holmstrom etal., 2010).

Robotic systems provide corporate benefits because they reduce production costs (Potkonjak et al., 2000). Sritex also conducts research and some processes (production) experience short cut, so the total supply chain is short. The production process from yarn to finished goods that previously took a month to just two weeks. Technology helps workers through the integration of information into the work environment, reduces the cognitive burden on workers and enables better performance of various operations in the field of logistics and manufacturing (Wang, et al., 2016).

\section{Impact of Implementation of Industry 4.0 on the Sritex Value Chain}

The textile industry will still improve in the future because of the increasing domestic and 
foreign market demand. Sritex will continue to improve and expand the marketing of its products to various parts of the world by relying on quality, the ability to supply supplies appropriately and quickly, and competitive prices. To find out the impact of Industry 4.0 on the value chain, there are two theories used namely: the theory of organizational change by Leavitt (1965) or what is called the horizontal dimension and the model of supply chain activities by Meyr \& Wagner (2004) cited in Kannegiesser (2008) or which is called the vertical dimension. In accordance with Leavitt's theory of organizational change, each organization consists of three interactive and highly interdependent components, namely technology, structure, and people.

Industry 4.0 causing companies to experience organizational changes that are interrelated, namely in terms of technology, structure, and people. Sritex's business activities are high-risk businesses, where in each step the business moves in large numbers both in terms of cost and resources used to achieve highly precise specifications. Therefore Sritex has two internal and external business strategies as a reference that must be used in facing business competition and maintaining the sustainability and development of the company's business in the future. The parent company of Sritex is PT. Huddleston Indonesia (formerly named PT Busana Indah Makmur), while the last shareholder of Sritex was Huddleston Enterprises Pte. Ltd and the Lukminto Family.

The scope of SRIL's activities includes businesses in the fields of spinning, weaving, dyeing, printing, improving textile and apparel. For the uniform business, Sritex is believed to be a uniform manufacturer of German soldiers and a number of other NATO countries. On June 7, 2013, SRIL obtained an effective statement from the Financial Services Authority (OJK) to conduct an Initial Public Offering of SRIL (IPO) of 5,600,000,000 with a nominal value of Rp100 per share at an offer price of Rp 240 per share. stock. These shares were listed on the Indonesia Stock Exchange (IDX) on June 17, 2013.
Sritex continues to innovate in a series of quality products that are issued. Sritex products are exported and used by corporations, military and international fashion outlets. Military forces from various countries use Sritex products, such as East Timor, Germany, Britain, Sweden and Australia. Sritex has succeeded in producing anti-infrared, insect repellent, anti-fire and anti-radiation nuclear military uniforms. Sritex strives to be at the forefront of the latest technology because the goal of Sritex is high quality, good price, and timely work. The machines used by Sritex come from abroad, namely Europe, especially Switzerland and Germany. Sritex invests US $\$ 100$ million in implementing automation, robotization and digitalization throughout the production line.

The application of artificial intelligence in smart factories has proven to have a large impact on the productivity and quality of the products produced (Li, et al., 2017). Sritex continues to conduct research to select which technology is most suitable for the textile and garment industry because the textile industry always uses sophisticated technology. The most felt impact from the use of technology is the increasing quality of production on all fronts. For garment production lines in particular, the technology needed is one that has high speed and multiple functions to strengthen production capacity. The role of humans is irreplaceable in the garment department. This means that naturally the garment production line will always be intensive labor.

Sritex runs an integrated Enterprise Resource Planning (ERP) system. This system connects data from the production division, marketing, logistics, human resources to finance and accounting. With the implementation of this system, the biggest impact is the creation of coordination automatically, because all data must be input and will be seen in the system live. In addition, efficiency is something that will naturally occur because this system will easily evaluate when there is a large discrepancy between the raw material and the final output. 
Quality control also occurs in stages and can be detected earlier, so that customer satisfaction and loyalty are expected to be maintained by the running of this system. Through improved procedures (SOP), the basic framework for installing this system can run smoothly and on time. Organizations carry out planning, decision making, control, and initiation through the autonomization of logistics (Broy, 2011). When associated with Corporate Governance, this system supports the creation of transparency, accountability, responsibility, independence, and fairness as the main values that are expected to be realized through the implementation of good corporate governance automatically and firmly. Such a system of "forcing" management, with the prerequisites of established procedures and internal policies.

The Textile and Textile Products Industry (TPT) in Indonesia has made a significant contribution to the country's foreign exchange for a long time. Indonesia's exports to the textile industry products continued to show improvement. The Ministry of Industry noted, the textile industry was able to contribute to foreign exchange of USD 11.87 billion or 8.2 percent of the total national exports in 2016. Meanwhile, the export value of this sector in the period January-May 2017 was around USD 5.11 million or an increase of 3.40 percent compared to the same period the previous year (Kemenperin, 2017).

Industry 4.0 will also provide developments in how humans are integrated in production activities. Stock \& Seliger (2016) explain the development towards a production situation where robots and human workers are very integrated and work collaboratively on shared tasks. Sritex is now more than $50 \%$ of its production to meet international market demand. The company that started from a shop in Pasar Klewer, Solo in 1966 was not $100 \%$ using machines (Industry 4.0 technology) because Sritex had employees. But Sritex does not abandon the technology needed to increase productivity. Sritex managed to achieve efficiency while maintaining product quality. Sritex employees number 15,000 (including management levels) spread throughout the factory. The use of digital machines did reduce the need for employees, but there was no dismissal at Sritex because it was absorbed by expansion. Sritex has 24 spinning factories, 7 weaving plants, 5 finishing factories and 11 garments.

\section{CONCLUSION}

Sritex has a value chain that focuses on the system, and how business inputs are converted into business outputs purchased by customers. The value chain is an activity that has added value, where the product that passes through the activities in the chain gets value at each stage. Sritex value chain analysis is distinguished in the main activities and supporting activities. The main activities are activities that are directly involved in the process of converting raw materials into output/ final products including the receipt of basic raw materials from suppliers and marketing of products/products to customers. Supporting activities are activities that are indirectly involved in the conversion process but support the main activities in their functions.

Sritex also applies the industry 4.0 technology application in its value chain, where it can affect products and processes, and enable increased efficiency and productivity of the company. To find out the impact of Industry 4.0 on the Sritex value chain, there are two theories used in this study, namely: the theory of organizational change by Leavitt (1965) or the so-called horizontal dimension and the model of value chain activities by Meyr \& Wagner (2004) quoted in Kannegiesser (2008) or what is called the vertical dimension. In accordance with Leavitt's theory of organizational change, the application of Industry 4.0 has an impact on three interactive and highly interdependent components, namely technology, structure, and people along the company's value chain.

\section{IMPLICATION}

\section{Theoretical Implications}

Increased productivity is at the core of every industrial revolution, especially for industry 4.0 which is a complex technological system that has 
a large influence on the industrial sector, because it introduces relevant advances, related to smart factories and future needs. The development of this technology is very important for the development of smarter manufacturing processes, which include devices, machines, production modules and products, which can independently exchange information, trigger actions and control one another, so as to create an intelligent manufacturing environment (Weyer et al. , 2015). Industry 4.0 has great potential in seizing economic and social opportunities through paradigm shifts regarding work organization, business models, and production technology (Kagerman etal., 2013).

\section{Managerial Implications}

Sritex has used a new manufacturing paradigm that is very focused on creating smart products and processes through the use of smart machines and the transformation of conventional manufacturing systems that are turned into smart factories. The company carries out integration, digitization, and use of flexible structures and smart solutions (Hajrizi, 2016). This manufacturing solution enables the creation of an intelligent environment along the value chain, thus impacting on flexible and adaptive process performance (Radziwon et al., 2014). For this reason, Sritex needs to continually create smart factory environments, which increase production efficiency, and enable meeting the needs of very complex markets (Kagerman et al., 2013). Companies can also come up with new, better business models that meet customer requirements through real time communication capabilities along the supply chain (Erol etal., 2016).

\section{REFERENCES}

Asmara, A., Purnamadewi, Y.L., Mulatsih, S \& Novianti, T. (2013). Faktor-faktor yang Mempengaruhi Perkembangan Investasi pada Industri Tekstil dan Produk Tekstil (TPT) Indonesia. Jurnal Manajemen Teknologi, 12(2), 140-160.

Bilalis, N., Wassenhove, L.N.V., Maravelakis, E., Enders, A., Moustakis, V., \& Antoniadis, A. (2006). An Analysis of European Textile Sector Competitiveness. Measuring Business Excellence, 10(1), 27-35.

Bimbaum, D. (2002). Life After Quota. Just-Style.com.

Broy, M. (2011). Cyber-Physical Systems. Springer.

Chandra, C., \& Kumar, S. (2000). An Application of A Systems Analysis Methodology To Manage Logistics in A Textile Supply Chain. Supply Chain Management: An International Journal, 5(5), 234-245.

Coyle, J.J., \& Ruamsook, K. (2014). Game Changing Trends and Supply Chain's New Normal. Supply Chain Quarterly 4.

Dangelmaier, W. (2001). A Demand-Driven Logistics Concept for The Fully Automated Rail System NBP. World Congress on Railway Research (WCRR).

Erol, S., Jäger, A., Hold, P., Ott, K. and Sihn, W. (2016). Tangible Industry 4.0: A Scenario-Based Approach to Learning for The Future of Production. Procedia CIRP 54,13-18.

Gambhir, D., \& Sharma, S. (2015). Productivity in Indian manufacturing: evidence from the textile industry. Journal of Economic and Administrative Sciences, 31(2), 71-85.

Hajrizi, E. (2016). Smart Solution for Smart Factory. IFAC-Papers OnLine, 49(29), 1-5.

Holmstrom, J., Partanen, J., Tuomi, J., \& Walter, M. (2010). Rapid Manufacturing in The Spare Parts Supply Chain: Alternative Approaches to Capacity Deployment. Journal of Manufacturing Technology Management, 21(6), 687-697.

Hunter, N.A. (1990). Quick Response in Apparel Manufacturing. Manchester: The Textile Institute. 
Hunter, N.A., \& Valentino, P. (1995). Quick Response Ten Years Later. International Journal of Clothing Science and Technology, 7(4), 30-40.

Irawan, H., \& Suryatoga, R. (2009). Analisis Rantai Nilai Industri Tekstil dan Produk Tekstil (TPT) di Indonesia. Jurnal Manajemen Indonesia, 9(3), 19-27.

Kagermann, H., Wahlster, W. and Helbig, J. (2013). Recommendations for Implementing the Strategic Initiative Industry 4.0. Munchen: National Academy of Science and Engineering.

Kannegiesser, M. (2008). Value Chain Management in The Chemical Industry. Global Value Chain Planning of Commodities. Physica.

Krajewski, L.P., \& Ritzman, L.P. (2001). Operations Management: Strategyand Analysis. NJ: Prentice-Hall.

Kuncoro, M. (2013). Indonesia's Textile and Its Products Industry: Recent Development and Challenges. The Business \& Management Review, 4(2), 126-139.

Lam, J.K.C., \& Postle, R. (2006). Textile and Apparel Supply Chain Management in Hongkong. International Journal of Clothing Science and Technology, 18(4), 265-277.

Law, L.C.K. (2016). An Exploratory Study of Vendor Logistics Performance Measurement for Logistics Management in Asia's Apparel Industry. DBA Thesis, Southern Cross University, Lismore, NSW.

Leavitt, H.J. (1965). Applied Organizational Change in Industry: Structural, Technological, and Humanistic Approach, Handbook of Organization, 1144-1170.

Li, B.-H., Hou, B.-c., Yu, W.-t., Lu, X.-b \& Yang, C.-w. (2017). Applications of Artificial Intelligence in Intelligent Manufacturing: A Review. Frontiers of Information Technology \& Electronic Engineering, 18(1), 86-96.

Mentzer, J.T., DeWitt, W., Keebler, J.S., Min, S., Nix, N.W., Smith, C.D. \& Zacharia, Z.G. (2001). What is Supply Chain Management? In J.T. Mentzer (Ed.), Supply Chain Management. Sage: Thousand Oaks.

Ngai, E.W.T., Peng. S., Alexander, P., \& Moon, K.K.L. (2014). Decision Support and Intelligent Systems in The Textile and Apparel Supply Chain: An Academic Review of Research Articles. Expert Systems with Applications 41,81-91.

Pereira, A.C., \& Romero, F. (2017). A Review of The Meanings and The Implications of The Industry 4.0 Concept, Procedia Manufacturing 13,1206-1214.

Porter, M.E. (1985). Competitive Advantage: Creating and Sustaining Superior Performance. New York: The Free Press.

Potkonjak. (2000). Dynamics of Anthropomorphic Painting Robot: Quality Analysis and Cost Reduction. Robotics and Autonomous Systems, 32(1), 17-18.

Radziwon, A., Bilberg, A., Bogers, M., and Madsen, E. S. (2014). The Smart Factory: Exploring Adaptive and Flexible Manufacturing Solutions. Procedia Engineering 69,1184-1190.

Ruel, S., Samuel, K.E., \& Vignard, N. (2013). Collaboration and Information Sharing in An Internal Supply Chain during An Innovation Project. Supply Chain Forum: An International Journal, 14(4), 32-41.

Schmidt, R., Mohring, M., Harting, R.C., Reichstein, C., Neumaier, P. \& Jozinovic, P. (2015). Industry 4.0 Potentials for Creating Smart Products: Empirical Research Results. International Conference on Business Information Systems, 16-27.

Stock, T., \& Seliger, G. (2016). Opportunities of Sustainable Manufacturing in Industry 4.0. Procedia CIRP 40, 536-541.

Strandhagen, J.W., Alfnes, E., Strandhagen, J.O., \& Vallandingham, L.R. (2017). The Fit of Industry 4.0 Applications in Manufacturing Logistics: A Multiple Case Study. Advances in Manufacturing, 5(4), 344-358.

Sudhana, P. (2017). Tinjauan Posisi Industri Tekstil dan Produk Tekstil Indonesia dalam Global Value Chain. Seminar Nasional Sains dan Teknologi Terapan V, Institut Teknologi Adhi Tama Surabaya, ISBN 978-602-98569-1-0.

Teng, S.G., \& Jaramillo, H. (2006). Integrating The US Textile and Apparel Supply Chain with Small Companies in South America. Supply Chain Management: An International Journal, 11(1), 44-55. 
Tjahjono, B., Esplugues, C., Ares, E., \& Pelaez, G. (2017). What does Industry 4.0 Mean to Supply Chain?, Procedia Manufacturing 13,1175-1182.

Wang, S., Wan, J., Li, D \& Zhang, C. (2016). Implementing Smart Factory of Industry 4.0: An Outlook. International Journal of Distributed Sensor Networks.

Weyer, S., Schmitt, M., Ohmer, M. and Gorecky, D. (2015). Towards Industry 4.0 - Standardization as The Crucial Challenge for Highly Modular, Multi-Vendor Production Systems. IFAC-PapersOnLine, 48 (3), 579-584.

Widodo, K.H., \& Ferdiansyah, E. (2010). Optimasi Kinerja Rantai Pasok Industri Tekstil dan Produk Tekstil Indonesia berdasarkan Simulasi Sistem Dinamis. AGRITECH, 30(1), 46-56.

Zhou, K., Liu, T., \& Zhou, L. (2016). Industry 4.0: Towards Future Industrial Opportunities and Challenges. International Conference on Fuzzy Systems and Knowledge Discovery, 2147-2152. 